\title{
Notes on Distichophyllum armatum (Daltoniaceae, Bryophyta) in Thailand
}

\author{
Orawanya Suwanmala, Wanwisa Juengprayoon, and Sahut Chantanaorrapint*
}

\begin{abstract}
Distichophyllum armatum (E.B. Bartram) B.C. Ho \& L. Pokorny, is newly discovered in lower montane forest in southern Thailand. A description and line drawing are provided, and its diagnostic characters and geographical distribution are briefly discussed.
\end{abstract}

KEYWORDS: bryophyte, diversity, moss, Thai-Malay Peninsula, taxonomy

\section{INTRODUCTION}

The genus Distichophyllum Dozy \& Molk. is the largest of several genera recently placed in the family Daltoniaceae (Ho et al., 2012). It comprises about 100 accepted species worldwide and is distributed mainly in tropical and subtropical regions (e.g. Frey \& Stech, 2009; Ho et al., 2012). The members of the genus are characterized by plants that are sparingly branched and usually complanately foliate, with unicostate leaves, marginal laminal cells mostly differentiated as a distinct border of elongate cells, and mitriform calyptrae (Frey \& Stech, 2009; Ho et al., 2010).

Thailand is one of the countries in Southeast Asia whose moss flora has been intensively studied (e.g. He, 1998; Akiyama, 2006). Recently, nine species and three varieties of Distichophyllum have been reported from this area (e.g. He, 1998; Akiyama, 2006; Ho et al., 2010). The discovery of new species and new records of mosses from Thailand (e.g., Ho et al., 2010; Printarakul et al., 2014; Hassama \& Chantanaorrapint, 2015; Sukkharak \& He, 2015; Juengprayoon et al., 2016), suggests that many bryophyte taxa await discovery in this country.

\section{MATERIALS AND METHODS}

During botanical surveys to Khao Ramrome Mt., Nakhon Si Thammarat province, in southern Thailand, some interesting collections of the genus Distichophyllum were discovered.

Department of Biology, Faculty of Science Prince of Songkla University, Hat Yai, Songkhla, 90112, Thailand

*Corresponding author: sahut.c@psu.ac.th

Date Submitted: 10 December 2017

Date Accepted: 09 April 2018
Based on the literature and comparisons with herbarium specimens, the unknown collections were identified as $D$. armatum (E.B. Bartram) B.C. Ho \& L. Pokorny which is a new record for the country. The distinctive characters of the species were illustrated with the aid of an Olympus drawing tube. The description and illustrations below are based on the recent collections in Thailand.

\section{TAXONOMIC TREATMENT}

Distichophyllum armatum (E.B. Bartram) B.C. Ho \& L. Pokorny, Bot. J. Linn. Soc. 170: 172. 2012. (Fig. 1)

इDaltonia armata E.B. Bartram, Farlowia. 1: 508. figs. 2124. 1944. Type: Philippines. Mindanao, Lanao Prov., vicinity of Dansalan (= Marawi), Sacred Mountain, alt. 700$800 \mathrm{~m}$, on culm of climbing bamboo, 3 Nov. 1938, Zwickey 638, (holotype: $\mathrm{FH}$; isotypes: $\mathrm{FH}, \mathrm{MICH}$ ).

Plants yellowish green to dark green, turning to brownish green in herbarium specimens, $0.65-1.2 \mathrm{~cm}$ long, 0.3-0.4 $\mathrm{cm}$ wide with leaves, rarely branched. Rhizoids reddish brown to magenta, dense at base of stem, sparse along ventral surface of stem, absent from apex. Stems dark green to brown, in cross section 8-12 cells across; epidermal cells in 1-2 layers, slightly thick-walled; cells of the cortex larger in size and thin-walled. Axillary hairs filiform, up to 2 per leaf, consisting of 2 cells long; terminal cell inflated, 25-32 $\mu \mathrm{m}$ long; basal and intermediate cells smaller, 12-18 $\mu \mathrm{m}$ long. Leaves monomorphic, not complanate, slightly recurved to flexuose when dry, erectspreading, strongly carinate at base when moist; narrowly elliptic to oblanceolate, $2.5-4.3 \times 0.7-1.2 \mathrm{~mm}$ wide; apex long acuminate to attenuate, acumen $320-400 \mu \mathrm{m}$ long; 


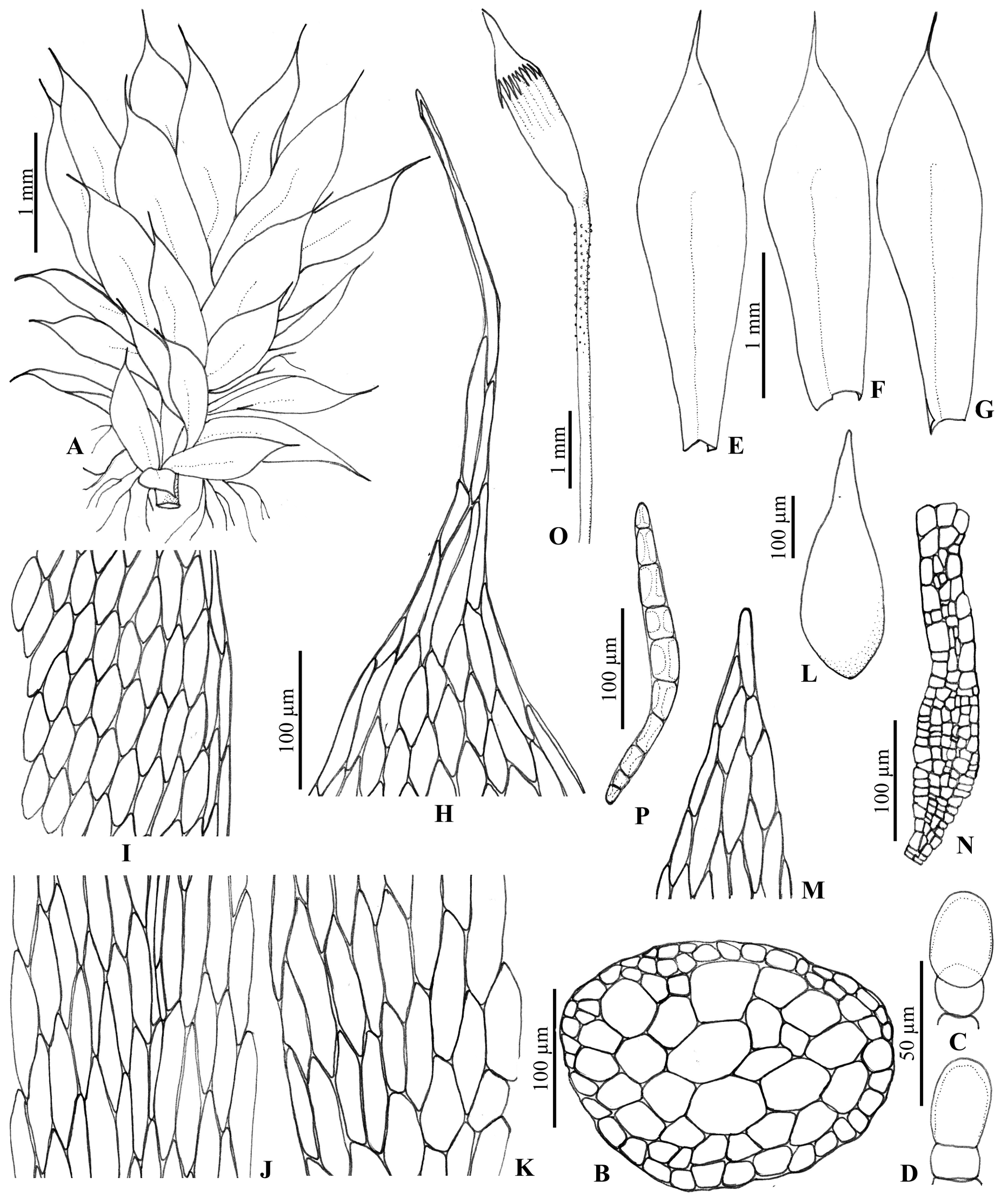

Figure 1. Distichophyllum armatum (E.B. Bartram) B.C. Ho \& L. Pokorny. A. Gametophyte. B. Cross section of stem. C \& D. Axillary hairs. E-G. Leaves. H. Cells at leaf apex. I. Cells at leaf margin. J. Cells at median part of leaf. K. Cells at leaf base. L. Perichaetial leaf. M. Apical part of perichaetial leaf. N. Archegonium. O. Sporophyte with calyptra. P. Gemma. Drawn by W. Juengprayoon from W. Juengprayoon 713 (PSU). 
margins entire; border weakly defined, consisting of $1-2$ rows of linear cells; costa weakly defined, about $3 / 5-2 / 3$ of leaf length. Lamina cells somewhat homogeneous, thin-walled, rhomboidal to oblong hexagonal; cells in upper half of leaf $80-$ $97 \times 20-25 \mu \mathrm{m}$; cells in lower half longer, 102-130 × 23-27 $\mu \mathrm{m}$.

Dioecious. Perigonial leaves not seen. Perichaetial leaves yellowish green, narrowly ovate, $0.4-0.45 \times 0.1-0.12 \mathrm{~mm}$ wide, acute to acuminate, entire. Seta slender, 6.2-7.1 mm long, reddish brown, smooth below, slightly scabrous above. Capsule erect, oblong, 2-2.5 mm long; operculum long rostrate, beak ca. $0.7 \mathrm{~mm}$ long; outer peristome teeth yellowish orange, lanceolate, papillose; inner peristome teeth as long as outer peristome, with high basal membrane. Calyptra mitriform, ca. $1 \mathrm{~mm}$ long, with fringed hairs at the base. Asexual reproduction by gemmae; gemmae light green, filiform, 320-345 $\mu \mathrm{m}$ long, occurring on adaxial surface of leaf base.

Specimens examined: Thailand. Nakhon Si Thammarat, Ron Phibun, Khao Ramrome, $945 \mathrm{~m}, 07^{\circ} 00^{\prime} 28.51 " \mathrm{~N}, 100^{\circ}$ 29'58.08"E, 28 Feb. 2015, W. Juengprayoon 205 (PSU), 28 May 2015, W. Juengprayoon 221 (PSU), 10 Apr. 2016, W. Juengprayoon 713 (PSU).

Distribution: Indonesia (Ceram, Sumatra), Malaysia (Pahang, Sabah), The Philippines (Mindanao), and new to Thailand (Nakhon Si Thammarat).

Habitat: In Thailand, Distichophyllum armatum was usually found growing on bamboo nodes in lower montane forest, at altitude $945 \mathrm{~m}$.

Notes: Distichophyllum armatum is easily separated from the other species of Distichophyllum in Thailand by 1) nearly terete plants with monomorphic leaves, 2) long acuminate to attenuate leaf apex, 3) leaf borders and costa weakly defined, 4) rhomboidal to long-hexagonal leaf cells, and 5) axillary hairs consisting of 2 short cells. Distichophyllum armatum might be confused with D. cuspidatum (Dozy \& Molk.) Dozy \& Molk., a widely distributed species, which also has monomorphic leaves with long-acuminate apices. Distichophyllum cuspidatum, however, differs from $D$. armatum in having well-developed leaf borders and the longcuspidate leaf apex. Lamina cells of $D$. armatum are rhomboidal to long hexagonal, whereas those of $D$. cuspidatum are uniformly round-hexagonal. Moreover, their axillary hairs also differ in shape and size.

Distichophyllum armatum was first described as Daltonia armata E.B. Bartram, based on a collection from Mindanao, The Philippines (Bartram, 1944). Based on recent molecular data, Ho et al. (2012) transferred it to the genus Distichophyllum. Distichophyllum armatum was previously known from The Philippines (Mindanao), Indonesia (Ceram, Sumatra), and Malaysia (Pahang, Sabah) (Tan \& Robinson, 1990; Mohamed \& Robinson, 1991; Ho et al., 2010). Akiyama (2006) reported Daltonia armata from Doi Inthanon National Park, northern Thailand, based on his collection, Akiyama Th-187 (HYO). However, after careful reexamination, this collection was determined as Daltonia angustifolia Dozy \& Molk. Therefore, this is a significant discovery being a new record for Thailand which also constitutes the northernmost location for Distichophyllum armatum. In Thailand, it is known only from Nakhon Si Thammarat province but it may have a wider distribution and occur in other areas of southern Thailand.

\section{ACKNOWLEDGEMENTS}

The authors are deeply grateful to the many years of encouragement given by the late Dr. B.C. Tan, the honoree of this special issue, to pursue a study of the moss diversity in Thailand. Sincere thanks to Dr. H. Akiyama for providing the specimens. This work was supported by the government budget of Prince of Songkla University (no. SCl610148S).

\section{LITERATURE CITED}

Akiyama, H., 2006. New records of mosses of Thailand. Tropical Bryology, 28: 59.

Bartram, E.B., 1944. New and noteworthy Philippine mosses. Farlowia, 1(4): 503-513.

Frey, W. \& M. Stech, 2009. Bryophyta (Musci, Mosses). In: Frey, W. (ed.), Syllabus of Plant Families. A. Engler's Syllabus der Pflanzenfamilien 13th ed. Part 3: Bryophytes and seedless vascular plants. Borntraeger, Berlin. Pp. 116-257.

Hassama, B. \& S. Chantanaorrapint, 2015. Species richness of bryophytes at Chao Pa waterfall, Trang province. Thai Journal of Botany, 7(1): 27-45.

He, S., 1998. The floristic composition and phytogeographical connections of Thai mosses. Journal of the Hattori Botanical Laboratory, 84: 121-134.

Ho, B.-C., B.C. Tan \& Y. Nathi, 2010. New and noteworthy records of Distichophyllum (Daltoniaceae, Bryopsida) and allied genera in Asia and Australasia. Tropical Bryology, 31: 106-122.

Ho, B.-C., L. Pokorny, B.C. Tan, J.-P. Frahm, A.J. Shaw \& D. Quandt, 2012. Molecular evolution and diversification of the moss family Daltoniaceae (Hookeriales, Bryophyta) with emphasis on the unravelling of the phylogeny of Distichophyllum and its allies. Botanical Journal of the Linnean Society, 170: 157-175.

Juengprayoon, W., M. Poopath \& S. Chantanaorrapint, 2016. 
Hookeria acutifolia (Hookeriaceae, Bryophyta), a genus and species new for Thailand. Polish Botanical Journal, 61(2): 237-241.

Mohamed, H. \& H. Robinson, 1991. A taxonomic revision of the moss families Hookeriaceae and Hypopterygiaceae in Malaya. Smithsonian Contributions to Botany, 80: 1-44.

Printarakul N., B.C. Tan, K. Wongkuna-Thananoppakun \& K. Santanachote, 2014. The Indian connection of the Thailand moss flora, with one new species, Fissidens elizbrowniae. Telopea, 17: 195-215.

Sukkharak, P. \& S. He, 2015. Schwetschkeopsis fabronia (Schwägr.) Broth. (Bryophyta: Fabroniaceae): a species new to Thailand. Telopea, 18: 371-374.

Tan, B.C. \& H. Robinson, 1990. A review of Philippine Hookeriaceous taxa (Musci). Smithsonian Contributions to Botany, 75: 1-41. 